\title{
Insights into the sources of antimony mineralisation associated with base metal epithermal deposits in SW England
}

\author{
EIMEAR DEADY ${ }^{1,2}$, KATHRYN MOORE $^{2}$ AND KATHRYN \\ GOODENOUGH $^{1}$ \\ ${ }^{1}$ British Geological Survey \\ ${ }^{2}$ Camborne School of Mines, University of Exeter \\ Presenting Author: eimear@bgs.ac.uk
}

The Herodsfoot epithermal lead-silver-zinc-antimony deposit in east Cornwall is a unique example of a $\mathrm{Pb}-\mathrm{Zn}$ epithermal vein deposit with significant associated antimony mineralisation. At Herodsfoot, Sb-bearing sulfosalts, bournonite and tetrahedrite are associated with galena and pyrite with minor sphalerite and chalcopyrite. Fluid inclusion microthermometric analysis shows that the ore minerals bournonite and sphalerite, and the gangue mineral quartz, were formed from low temperature fluids, with homogenisation temperatures of $110-150^{\circ} \mathrm{C}$, and average salinity of 20 wt. $\% \mathrm{NaCl}$ equivalent. The low homogenisation temperature is comparable to that for regional $\mathrm{Sb}$-free epithermal $\mathrm{Pb}-\mathrm{Zn}$ deposits. Metals in these deposits have been shown to be transported by low temperature brines sourced from regional sedimentary basins [1].

The source of the metals for the base-metal deposits is postulated to be in volcanogenic Devonian and Lower Carboniferous stratiform syn-sedimentary mineralisation hosted by metasedimentary rocks [2]. Antimony sulfosalt-base metal assemblages in north Cornwall are associated with carbonatisation of basalts by fluids transported in a brittle-ductile shear zone [3] but $\mathrm{CO}_{2}$-rich fluid inclusions have not been identified at Herodsfoot. Antimony deposits of Variscan age in north west France have a statistically significant, spatial association with dolerite of Carboniferous age [4-5]: the dolerites are interpreted as both a potential source of the antimony and as a pathway for mineralisation. We investigate the spatial relationship between the antimony mineralisation at Herodsfoot and the known mafic igneous lithologies. We further consider different potential sources of antimony using LA-ICP-MS mineral trace element data.

References:

[1] Gleeson, et al. (2001) Geochim. et Cosmochim. Acta, 65, 2067-2079

[2] Scrivener R, et al. (1989) EUG V., 125

[3] Clayton, R. (1993). Proc. of the Ussher Soc., 8, 105-105

[4] Pochon A, et al. (2016) Terra Nova 28:138-145

[5] Pochon, A., et al. (2018). Ore Geology Reviews, 97, 109- 